\title{
Cbronicle of Research in the Field of Legal and Constitutional History in France in 2018
}

Keywords: scholarly events, France, conferences, publications, academic degrees.

Słowa kluczowe: wydarzenia naukowe, Francja, konferencje, publikacje, stopnie naukowe.

Over the course of 2018 there were a number of significant developments in the area of legal and constitutional history in France and a large number of academic works were produced. Only the most relevant developments have been considered below. Publication dates have been omitted since this chronicle is by definition restricted to events having taken place in 2018.

\section{2018: A year of commemorations}

Over the course of 2018, a number of commemorations of national and international events took place. These commemorations were the subject of considerable attention in the field of jurisprudence.

The commemoration of the centenary of the end of the First World War heralded by a number of important studies into the significance of this period from a legal historical perspective. In 2012, the French Government established a special organisation, the "Mission for the Centenary of the First World War" (Mission du centenaire de la Première Guerre Mondiale) to promote the centenary, organise the program for its commemoration, and undertake research. The Mission for the Centenary of the First World War is the result of cooperation between different government departments, administrative bodies, and centres of research. Under its patronage, many events took place and brought together legal historians, legal theorists, and legal practitioners. The objective of the research undertaken was to understand how the exceptional set of circumstances caused by the First World War influenced the law and its development, and to consider the impact on courts and tribunals. 
Amongst other bodies, the French Council of State (which has a dual role, being both an advisor to the state and the final appellate court in respect of litigation involving administrative bodies) was particularly active in its participation in these events. This institution was responsible for editing a widely published compendium of academic articles analysing the role played by the Council of State during the First World War (Le Conseil d'État et la Grande Guerre, La documentation française). Furthermore, the Council of State published on the Internet copies of the advice it provided to the state over the course of the First World War. It also facilitated public access to its archives. In addition, the French Court of Cassation held a conference on similar topics on 9 November 2018 entitled: The Court of Cassation and the Great War.

As part of the commemoration of the centenary, universities and centres of research released a number of important publications and various public meetings were held. Among these initiatives, the Cujas Library in Paris put together a rich virtual exhibition about the role played by French law faculties during the First World War. Some interesting documents and a large bibliography can be consulted at the following URL: http:// expo-grande-guerre-biu-cujas.univ-paris1.fr/

In 2018, France also celebrated the sixtieth anniversary of the Constitution of the Fifth Republic. Promulgated on 4 October 1958, the Constitution of the Fifth Republic is, after the Constitution of the Third Republic, the longest-standing political system to be established in France since the Revolution. Since its adoption, the Constitution has been amended twenty-four times. Not all of those amendments, however, have been of equal significance. The most important amendment came in 1962, when it was decided by referendum that the French people would directly elect the President of the Republic by universal suffrage. The most recent amendment was voted into law on 23 July 2008. Since that date, a number of proposed amendments were abandoned due to a lack of political consensus. The Constitution of the Fifth Republic has resulted in a parliamentary system that is dominated by the executive branch. It is sometimes criticised, with opponents of the regime taking the view that the concentration of powers in the hands of the President of the Republic is prejudicial for democracy. But the present constitution is widely regarded to have achieved its goal of stability and efficiency.

Two collaborative books review this history. Les 60 ans de la Constitution (Sixty Years of the Constitution), Dalloz, edited by Prof. Dominique Chagnollaud de Sabouret and Dr. Benoît Montay, weaves together political testimonies and academic analysis. $L a$ Constitution de la Ve République, 60 ans d'application (The Constitution of the Fifth Republic, sixty years of application), LGDJ, edited by Prof. Philippe Blacher, is a conceptual reflection on the application of the Constitution and on the question of what amendments may yet be desirable. Such collaborations have brought together specialists in administrative/constitutional law and political science. 


\section{Conferences}

Many events were held, including:

The Institut des sciences juridiques et philosophiques de la Sorbonne ("Institute of legal and philosophic sciences of the Sorbonne") organised, with the assistance the National Scientific Research Centre and the Mission of the Centenary of the First World War, a conference on the topic Assistance, Welfare Funds, and Insurance in the Great War - A Change of Paradigm (Late 19 $9^{\text {th }}$ Century to the Early 1920s). The event took place at the Institut national d'histoire de l'art (National Institute of the History of Art) on 17 and 18 January 2018. The concepts of state assistance, welfare funds, and insurance were developed and transformed by the Great War. The conference proposed a new methodological approach to such questions.

An international conference took place at the Paris Nanterre University on 25 and 26 January 2018 on the topic of The History of Legal Publishing (1 $6^{\text {th }}-21^{\text {st }}$ Century). Nearly forty speakers debated current and historical issues relating to the editing of legal publishing. It emphasized the need to expand knowledge in this underdeveloped academic field.

The $15^{\text {th }}$ annual conference of the International Medieval Society, in partnership with Panthéon-Sorbonne University (Paris I) and Sorbonne-Nouvelle University (Paris III), was held in Paris between 28 and 30 June 2018. The topic was "truth and fiction". Professor Patrick Boucheron, who holds the chair in the field of the history of power in Western Europe at the Collège de France, gave the inaugural speech where he analysed truth in tales. Numerous sessions on various topics were organised. For instance, the opening session concerned "discourses on Truth (history, law, literature)", whereas others sessions dealt with theological studies as "revealing Truth".

At the end of September, the $26^{\text {th }}$ Conference on Archaeology and History in Périgord, which is traditionally held in the city of Périgueux, dedicated to the study of "castle and justice".

\section{Publications}

Among numerous publications, it is appropriate to mention:

Paul Chauvin-Hameau, L'obligation militaire sous l'Ancien Régime (Military obligation under the Ancien Régime), ed. Institut universitaire de Varenne. This book is the publication of the author's doctoral dissertation. Professors Brigitte BasdevantGaudemet and François Saint-Bonnet edited it.

Wojciech Fałkowski, Yves Sassier (eds.), Confiance, bonne foi, fidélité, La notion de fides dans la vie des sociétés médiévales (Ve-XVe siècles) (Truth, Good Faith, Loyalty, the Notion of Fides in the Life of Medieval Societies ( $6^{\text {th }}-15^{\text {th }}$ centuries)), ed. Classiques Garnier. This book brings together papers from international researchers on the Latin concept of fides and its evolutions in spaces and times during the Middle Ages. 
Claude Gauvard, Condamner à mort au Moyen Âge. Pratiques de la peine capitale en France XIIIe-XVe siècle, (Death Sentences in the Middle Ages. Practices of Capital Punishment in France $13^{\text {th }}-15^{\text {th }}$ Centuries), ed. PUF. The famous historian of the Middle Ages and specialist in the history of crime and justice, Claude Gauvard, provides an analysis of the implementation of the death penalty in medieval France that challenges the traditional notion that the Middle Ages was a bloody period.

Jacques Krynen, Le théâtre juridique, Une histoire de la construction du droit (The juridical theatre, A history of the construction of law), ed. Gallimard, coll. NRF. The objective of the book is to give a long-term perspective of the position that law occupied in society. It describes the eternal competition between legislators, judges and academics. This competition created an inevitable tension as concerns the binding effect of law.

Marine Ranouil, Nicolas Dissaux (dir.), Il était une fois... Analyse juridique des contes de fée (Once Upon a Time... A Legal Analysis of Fairy tales), ed. Dalloz. This collection of articles deals with a cross-study of law and tales with papers such as "Savigny and the Grimm brothers" or "the norm in fairy tales".

Caroline Regad, Les juristes de Louis XIII et de Richelieu, théoriciens de l'État (Louis XIII ${ }^{\text {th }}$ and Richelieu's Lawyers, the State's theoreticians), ed. LGDJ. This book is the publication of the author's doctoral dissertation. Professors Christian Bruschi and Eric Gasparini supervised the thesis. The reign of Louis XIII is a point of transition from royal rights to State Law. Lawyers of the royal entourage played an active role in this movement.

Alix Rodet-Profit, Le contrat d'assurance maritime à Rouen dans l'Ancien droit (The Marine Insurance Contract in Rouen in the old law), pub. in Institut universitaire de Varenne. This book is the publication of the doctoral work of the author supervised by Professor André Castaldo. Rouen was the only place in France with a registry of insurance policies. Judges and merchants elaborated rules to create a fair contractual balance.

Tribonien, Revue critique de legislation et de jurisprudence (Tribonien, Critical review of legislation and jurisprudence) is a new journal published for the first time in 2018. Tribonien was a famous jurisconsult who played an active part in the drafting of the Justinian Code. Under its auspices, the authors of the review hope to develop a critical examination of positive law using historical and comparative approaches. The journal is edited by the Société de législation comparée ("Society for comparative legislation") and directed by Professors Nicolas Cornu Thénard and Nicolas Laurent-Bonne.

\section{Academic life}

In 2018, three researchers were appointed as full professors following the competitive aggregation exam in legal history (by order of merit):

- Elena Giannozzi, Professor at the Reims-Champagne-Ardennes University, author of a doctoral thesis entitled Le bonus vir dans le droit romain (The Bonus Vir in Roman Law).

- Frédéric Constant, Professor at the Nice Sophia Antipolis University, author of a doctoral thesis entitled Le droit mongol dans l'État imperial sino-mandchou 
(1644-1911): entre autonomie et assimilation (Mongolian Law in the SinoManchu Imperial State (1644-1911): Between Autonomy and Assimilation).

- Nicolas Kermabon, Professor at the University of the French West Indies, author of a doctoral thesis entitled Le douaire des duchesses de Bretagne, XIIIe-XVe siècles (The Duchesses of Brittany's Dower, $13^{\text {th }}-15^{\text {th }}$ Centuries). 